\title{
Live-work Tactics in the Suburban House and their Effects on Public Spaces in the Peripheral Neighbourhoods of Rio de Janeiro
}

\author{
Ana Slade and Guilherme Lassance \\ Federal University of Rio de Janeiro, Postgraduate Program in Urbanism (Prourb), Brazil \\ anaslade@fau.ufri.br | guilherme.lassance@fau.ufri.br
}

\begin{abstract}
Housing production in Brazil continues, for the most part, to be tied to the mono-functional paradigm. Social housing developments, gated communities and new neighbourhoods are conceived according to modern, functional zoning logic. However, in reality, the Brazilian way of life subverts this logic where its expression produces urban spaces that don't correspond to what is originally planned or imposed by regulation.

This paper presents the outcomes of an investigation conducted on suburban houses in Rio de Janeiro, which have been informally transformed to accommodate multiple activities ranging from living areas to workspaces. Vast areas of lots generally occupied by singlefamily houses characterise the low-income suburbs of Rio. In these areas, the pressing need families face to increase their income, a need associated with the general lack of infrastructure - including local commerce and facilities - fosters the development of informal economies, which in turn transforms the built environment and effecting the public space. A fragment of one of these peripheral neighbourhoods is analysed in this paper through the mapping of commercial and professional activities that take place in singlefamily houses. The urban environment of streets in which these kinds of activities are taking place is compared with neighbouring streets in which no such activities are apparent. The investigation consists of a consideration of the social and spatial effects of informal practices occurring within the formal city. The suburban houses are analysed as privileged spaces in which the local way of life can be observed and acknowledged as being intrinsic to a specific social and economic reality. Both spatial and building solutions are thereby recognised as valuable lessons which urge practitioners to consider alternatives to the way in which housing projects and city planning have been previously defined.
\end{abstract}

Keywords: peripheral neighbourhoods, live-work architecture, public space

To cite this article:

Slade, A. and Lassance, G. (2019). Live-work Tactics in the Suburban House and their Effects on Public Spaces in the Peripheral Neighbourhoods of Rio de Janeiro. The Journal of Public Space, 4(2), 8I-I00, DOI I0.3289I/jps.v4i2.I205

This article has been double blind peer reviewed and accepted for publication in The Journal of Public Space.

This work is licensed under a Creative Commons Attribution - Non Commercial 4.0 International License https://creativecommons.org/licenses/by-nc/4.0/ 


\section{Introduction}

Major paradigm shifts in the organisation and planning of cities are deeply related to the conformation of the workspace and its relation to dwelling. In the pre-industrial period, domestic spaces were utilised as mixed-use living and working areas. In the same family environment commercial activities were run alongside those pertaining to daily life. The new mode of production introduced by industrial capitalism lead to the spatial separation of dwelling places and workplaces and as a result, urban planning principles began to mirror the spatial segregation of functions that defined the industrial age. Along with live-work typology, small-grain, diverse and mixed uses were abolished the strictly residential areas of proletarian suburbs were born.

After decades of planning based on functional zoning, criticisms of the modern city began to emerge. Among others, author Jane Jacobs claimed, in the 1960s, that diversity and density should be considered as necessary qualities to achieve vitality and safety in the city.

In the late 19th and early 20th centuries, despite a markedly slow process of industrialisation, Rio de laneiro went through deep foundational transformations specifically in relation to its economy and systems of production. Similarly to other large cities in the world, economic shifts generated intense population growth, accompanied by an increase in the number of precarious dwellings. The desire to transform the image of the city, to embody the expression of a modern capital, drove the displacement of the lower and middle-class populations away from the city to its surrounding areas. However, unlike the Howard's 'Garden City' in England or 'habitat ideology' in France (Lefebvre, 1991), no development project emerged to serve the displaced population. Instead, these proletarian suburbs grew predominantly without planning and were characterised by real estate driven processes which entailed subdividing former farmland into small urban plots coupled with the spatial segregation of activities, thus generating extensive strictly-residential areas.

While in the United States, interest in hybrid uses re-emerged from critical reevaluations of urban planning policies based on functional zoning; Rio de laneiro, continues to be governed by regulations implemented in the 1970s - which have not yet been substantially revised - and continue to be considerably influenced by the modern principles of use segregation (Lassance et al., 20I2: 37). However, although there is much discussion around and policies against intensifying mixed use in North America, consolidated residential areas are vast and heavily shielded for mixed use. Diversely, in Brazil, home-based informal entrepreneurial activities have proliferated in suburban residential neighbourhoods despite legislation, and have profited from a lack of inspection from Governmental bodies.

Such activities - and their impact on urban space in residential suburban neighbourhoods of Rio de laneiro - are the phenomena being analysed in this article. The spontaneous transformation of the suburban house and the relationships between spatial and building solutions and local street life are recognised as valuable nonhegemonic innovative practices produced by different individuals and socio-spatial contents. By doing so, the research reveals a suburban reality that transcends the condition of scarcity and economic dependence, which often form the narrative used by locals to describe Rio de laneiro's suburbs (Fernandes, 20I I).

The suburban residents' everyday practices - their 'making do' in terms of living and 
carrying out economic activities - are treated and analysed as a resource with the potential to facilitate alternative housing policies and city planning strategies. In understanding these informal entrepreneurial activities within the formal city, the present research opens up a territory of investigation on the ordinary production of the city and its architecture, something that designers and planners often fail to consider (Walker, 2010). The suburban houses are analysed as valuable spaces in which the local lifestyle can be observed and acknowledged as being intrinsic to a specific social and economic reality: in which dwelling is often associated with professional activities and income generation.

\section{The 'suburb' of Rio de Janeiro - from aristocracy to proletariat}

In Rio de Janeiro, the concept of suburb has changed over time, absorbing a singular local connotation (Soares, 1960; Fernandes, 201 I). Its current definition is in direct contrast to what prevailed until the late 19th century, a time when "suburb" referred to the outskirts of the city, which served primarily as a rural retreat for wealthy families and the backdrop to farming activities (Fernandes, 20I I:53-55). Even after the construction of the first railway line in 1858 , for decades suburbs would remain the territories of the upper classes. At that time, the plans for the outskirts of Rio were similar to those found in the modern rail suburbs of Europe and North America, created for the middle and upper classes (Fernandes, 20I I: 57).

However, from the beginning of the 20th century onwards, the attributes related to the concept of suburb in Rio drastically changed (Fernandes, 201 I: 44). Faced with the ideological needs of a capitalist society and as a result of the development of major urban reforms, the suburbs became the subject of stigmatisation where they began to be associated with the neighbourhoods served by the train lines that were used by the lowincome classes. From this point on, discriminatory policies were adopted to deal with the periphery. They were linked to the process of "opening the suburbs to the proletariat" (Abreu, I 987: I5) and the trinomial "train / suburb / proletarian" - a typical depiction of the suburbs in Rio de Janeiro (Fernandes, 20I I: 143). This context favoured the development of the enduring social and spatial segregation of the proletarian suburbs. During the first three decades of the $20^{\text {th }}$ century, the residents of these neighbourhoods had to seek independent ways of living and working, with little to no State intervention in the social and urbanistic domain, let alone dedicated public space. During the first three decades of the $20^{\text {th }}$ century, the residents of these neighbourhoods started to seek independent ways of living and working

\section{From farms and rural properties to land parceling for urban developments}

The suburb came to be occupied by the proletariat because of the imperative of the accelerated growth of the city, of the migration flows, of the real estate dealers who promoted the percolation of the farmland in order to transform it into new urban developments that were cheap because of the lack of infrastructure Fernandes, 20I I: I5I

The process of urbanisation of the many peripheral neighbourhoods known today as 
suburbs of Rio de Janeiro began in the 1870s (Santos, 1987). Led by land-owning families, the auctioning of individual parcels or big plots of land was triggered by the opportunity to transform the land into a "commodity" (Pechman, 1985: I25, I26). Population growth and the consolidation of the urban fabric belonging to the region did not take place until after 1890, accompanied by a significant swell of passengers embarking on suburban trains. This increase in ridership was coupled with a rise in real estate ventures which lead to the densification of the periphery and the expansion of the city limits (Pechman, 1985: 127).

Attempting to escape from increasingly high rents in more central areas, the emerging middle class formed the first main social layer in the initial stages of the occupation of the railway suburbs. An opportunity had presented itself for them to buy a small piece of land and acquire ownership of their dwellings (Pechman, 1985: 14, 42).

In the city centre, as well as in some suburban areas which had mixed-use developments along their main streets, rail or tramway lines, the "sobrado" - the local name given to two storey houses aligned to the street - was a dominant typology. The sobrado (Figure I) is a live-work typology, which combines a commercial store on the ground floor with independent access to the second floor, where the owner's family typically lived.

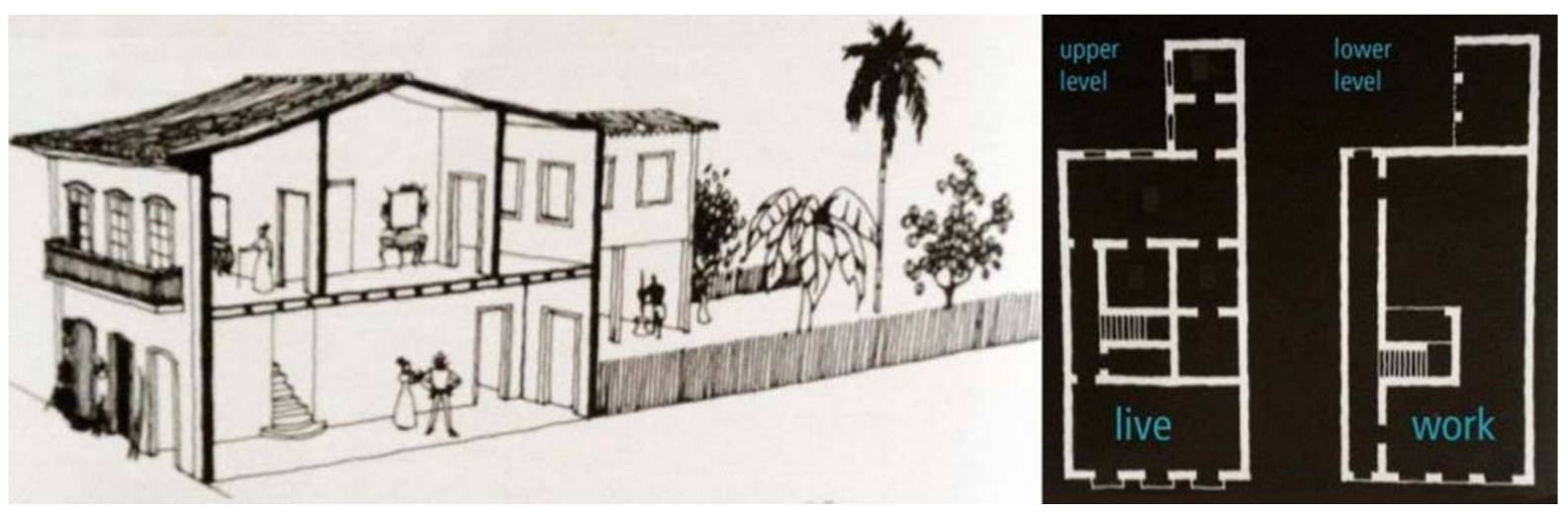

Figure I.The sobrado.

Source: authors' elaboration based on drawings by Reis Filho (1978).

In the second stage of the urbanisation process of Rio's periphery, as transportation became more accessible, the poorer strata of the population joined the middle class in these suburban railway neighbourhoods. Many houses were subsequently built-for-rent by independent owners and real estate companies (Pechman, 1985, pp.40-43).

\section{Transportation and other driving forces in the production of the suburban space}

These suburbs do not have their own existence, independent from the center of the city, on the contrary, their life is common, their relations very intimate and frequent Aureliano Portugal, Jornal do Comércio, 20/06/I904 apud Pechman, 1985: 53 
The suburban territories were consolidated along the four main railway lines. In addition, a somewhat dense network of tramway lines "sewed" links between the first areas to be urbanised, which were concentrated around the train stations, and more scattered developments (Pechman, 1985: 52).

We can therefore conclude that the residential neighbourhoods that are the object of this study were a repository of houses, the result of the parceling of land understood as a mere commodity, which served to "store" the massive population that constituted the working class, who sold their labor in the most central and now privileged areas of the city (Bonduki and Rolnik, 1979). Nowadays, the suburban region is composed of a patchwork of formal and informal settlements (favelas). Within the formally developed settlements, one can find many strictly residential neighbourhoods. Within the formally developed settlements, one can find many strictly residential neighbourhoods featured by the lack of amenities, shops and services. The replacement in the middle of 20th century of tramway lines with bus routes worsened even more the connectivity of these areas with district centres commercial hubs.

The highly profitable business of mono-functional housing development is deeply entrenched in Rio's periphery and continues to be the dominant model of urbanisation.

\section{Case study: residential fragment in the district of Irajá}

Home-based informal economy refers to a wide range of activities from artisan production to small shops and represents a common practice occurring in the peripheral neighbourhoods of large Brazilian cities. Often, the proliferation of such activities happens in areas dominated by single-family houses that are distant and disconnected from any major commercial hub. The case study presented here offers an illustration of a typical situation found in residential areas in the suburbs of Rio de Janeiro. The first suburbs developed with daily commuters in mind were situated in the North Zone of the city. For this reason, focusing this research on this area in particular was deemed to be of the utmost relevance.

Furthermore, the determining factor in the selection of Iraja for the case study - from among the many areas initially mapped - was the issue of security. Following initial efforts to establish contact with local agents and ensuing conversations, this area was identified as being the safest one in which to conduct our field research. Consequently, the selection of Irajá from among other potential representative urban fragments was not the result of a selection process conceived on the basis of establishing the most ideal or most representative area in the Northern periphery of the city (Figure 2). The neighbourhood of Irajá is located in the North Zone of Rio de Janeiro, the most populated area of the city. The North Zone consists of 87 districts which are home to 42 per cent of the city's population and presents a population density of 10, I 85 per $\mathrm{km} 2$, which is the highest rate in the city of Rio de Janeiro (SEBRAE/RJ, 20I5). In the year 2000 , the North Zone region presented the lowest average income per household in Rio de Janeiro and this rate in the neighbourhood of Irajá was even lower, getting close to one third of North Zone average income per household (IBGE, 20I0). 


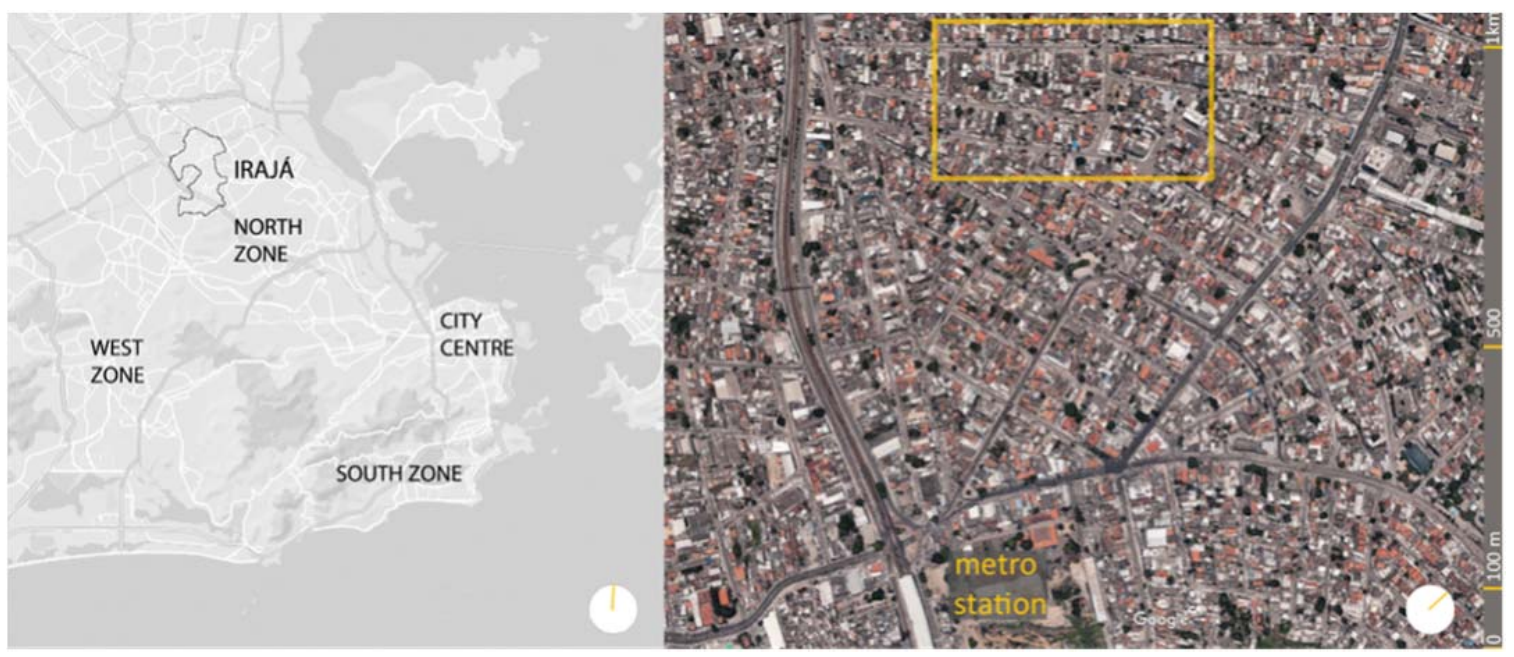

Figure 2. Studied area in Irajá neighbourhood, Rio de Janeiro.

Source: authors' elaboration based on Google Earth.

However, at the time this region was home to the highest proportion of employees with a formal job contract ( 57.9 per cent) and 20 per cent of workers were selfemployed. In 2015 the unemployment rate in the Metropolitan Region of Rio de Janeiro was 6 per cent, a figure which has climbed steadily, reaching 14.3 per cent in the first quarter of 2017 (IBGE, 2017).

\section{Methods}

The study began with on-site observations and cartographic analysis to facilitate a rounded understanding of the built environment. The pioneering survey undertaken in the 1970s by Carlos Nelson Ferreira dos Santos and a multidisciplinary team in Catumbi — another suburban neighbourhood of Rio de Janeiro - served as a main reference point for the development of our analysis, in relation to the physical aspect of the built environment and the social practices that take place in it. Carlos Nelson was a Brazilian architect and urban planner and a locally well-known activist who dedicated himself to various causes related to social housing, favelas and the urban periphery as a whole (Costa and Silva, 2017). His work on urban and architectural design was always performed in close contact with the communities, promoting the importance of "talking about the city from the users' point of view" and establishing close contact between the architect and urban planner and the expression of "daily life, with its inevitable mixture, with its complex and changing variables combinations" which, in his understanding, should be the source and the focus of urban knowledge (Santos, 1985).

Ferreira dos Santos' approach served therefore as a framework for the definition of our categories of analysis. The first step was the identification of physical and spatial categories, focusing on the relationship between architectural and urban space elements, such as the: house; street; yard; sidewalk; porch; street surfacing — intended to accommodate vehicles; window; door; gate; counter; and the overhanging roofs and awnings. The physical and spatial categories were then related to cultural values and social activities. The notions of public and private, of formality and informality and 
visibility and invisibility are all values that are applicable to the initial identification of physical and spatial categories. As a result of such application, we produced an articulated set of spaces, associated with an articulated set of values. Finally, a third system was considered: the system of activities or uses that applies to each of the two aforementioned sets, thereby allowing us to add other categories such as working, living and enjoying leisure time or playing. The analytical process is thus based on the combination of these three groupings where they are integrated to form a three-system analysis.

\begin{tabular}{|c|c|c|}
\hline $\begin{array}{l}\text { PHYSICAL SPATIAL } \\
\text { CATEGORIES }\end{array}$ & VALUES & ACTIVITIES \\
\hline $\begin{array}{l}\text { street } \\
\text { house } \\
\text { yard } \\
\text { wall } \\
\text { fence } \\
\text { roof } \\
\text { counter } \\
\text { window } \\
\text { door } \\
\text { porch } \\
\text { overhanging covering } \\
\text { etc. }\end{array}$ & $\begin{array}{l}\text { public - private gradation } \\
\text { formality / informality } \\
\text { visibility / invisibility }\end{array}$ & $\begin{array}{l}\text { live } \\
\text { work } \\
\text { play }\end{array}$ \\
\hline
\end{tabular}

Table I. Three-System Analysis.

Source: authors' elaboration based on Santos et al. (1985).

Our analysis focused on the boundary between public and private spaces and focused on an evaluation of the production of "common spaces". The suburban house is thus analysed in terms of its relationship to its residents, their neighbours and other passersby. The relationship between the architecture of the house and its surrounding urban environment is highlighted as a key factor for the constitution of the street and the neighbourhood itself. The gradation between public and private spaces, as proposed by Santos et al (1985), is a fundamental concept in the developed analysis. In the observed suburban reality, the opposition between the spheres of the house and the street does not present the outlined schematic rigidity.

We started our on-site survey by walking along the streets of the chosen urban fragment and observing the boundaries between public and private spaces.Visible economic activities were mapped, along with signs on facades. We sought to identify activities that had the potential to promote interactions in public space, in a variety of ways. During this stage, we also observed the social practices taking place in public space and counted the number of passers-by and people staying and interacting along the sidewalks. The initial mapping of economic activities was later complemented with an Internet survey on service and product advertisements. During the second stage of our study, an on-site survey was carried out in some of the business premises that were found to promote interaction with public space and serve as spaces for community 
gatherings. In this phase, we looked at the social dynamics inherent in these work spaces both in terms of their relation to the street and the internal layout of the houses. We noted the changes made to the spatial organisation of the house to incorporate workspaces, such as the introduction of barriers to separate public and private spaces and spatial interfaces that provide greater interaction: facilitated by a smoother gradation between public and private spheres. Informal conversations with owners, customers and other neighbours were also undertaken.

\section{Learning from the suburban house tactics}

The scarcity of formal local shops and other facilities, as well as spaces for social gathering in the neighbourhood, combined with the need to generate income, becomes an opportunity for the development of an informal economy.

Although local legislation prohibits mixed-use developments and conducting business activities from private residences, lack of enforcement by public authorities in these suburban areas allows the proliferation of informal economic activities linked to the public space. This renders the environment more conducive to the experimentation of spontaneous solutions. These urban peripheries are therefore a favourable ground for the proliferation of informal "tactics".

The concept of tactics is employed here according to Michel de Certeau's definition which distinguishes it from "strategy" (Certeau, 1984: 34-39), which he refers to as the calculation (or manipulation) of power relations, a Cartesian attitude, typical of modern science, politics and military action. Tactics on the other hand are defined as calculated actions determined by the absence of a proper locus, therefore they occur on and within a terrain imposed and organised by the law of an external power. A tactic does not have the option of operating as part of a general plan, in Certeau (1984: 37) words:

It operates in isolated actions, blow by blow. It takes advantage of "opportunities" and depends on them, being without any base where it could stockpile its winnings, build up its own position, and plan raids. What it wins it cannot keep. This nowhere gives a tactic mobility, to be sure, but a mobility that must accept the chance offerings of the moment and seize on the wing the possibilities that offer themselves at any given moment. It must vigilantly make use of the cracks that particular conjunctions open in the surveillance of the proprietary powers. It poaches in them. It creates surprises in them. It can be where it is least expected. It is a guileful ruse. In short, a tactic is an art of the weak.

The users actions in the creation of these open working devices for the street transform the urban space of the residential neighborhood. New appropriations and demarcations of the public space are provided which do not correspond to the system imposed by the pre-existing settlements, changing the nature of the predetermined space, as Certeau points out (1984, p. xviii):

In the technocratically constructed, written, and functionalized space in which the consumers move about, their trajectories form unforeseeable sentences...Although they are composed with the vocabularies of established languages ... and although they remain subordinated to the prescribed syntactical forms (temporal modes of schedules, paradigmatic orders of space, etc.), the trajectories trace out the uses of others interests and desires that are neither determined nor captured by the systems in which they develop. 
With this in mind, the built environment in the neighbourhood of Irajá is analysed according to a two-layered approach. The first layer refers to its existing morphological elements, dominated by the repetition of a basic unit: the urban lot, approximately eight to ten metres wide by 25 to 50 metres deep, occupied by single-family houses and surrounded by narrow streets and sidewalks. In addition to this physical context is a second layer, formed by users' responses to the physical environment in which they perform their everyday practices. We can therefore observe these two distinct scenarios as they unfold on the streets of the neighbourhood in question.

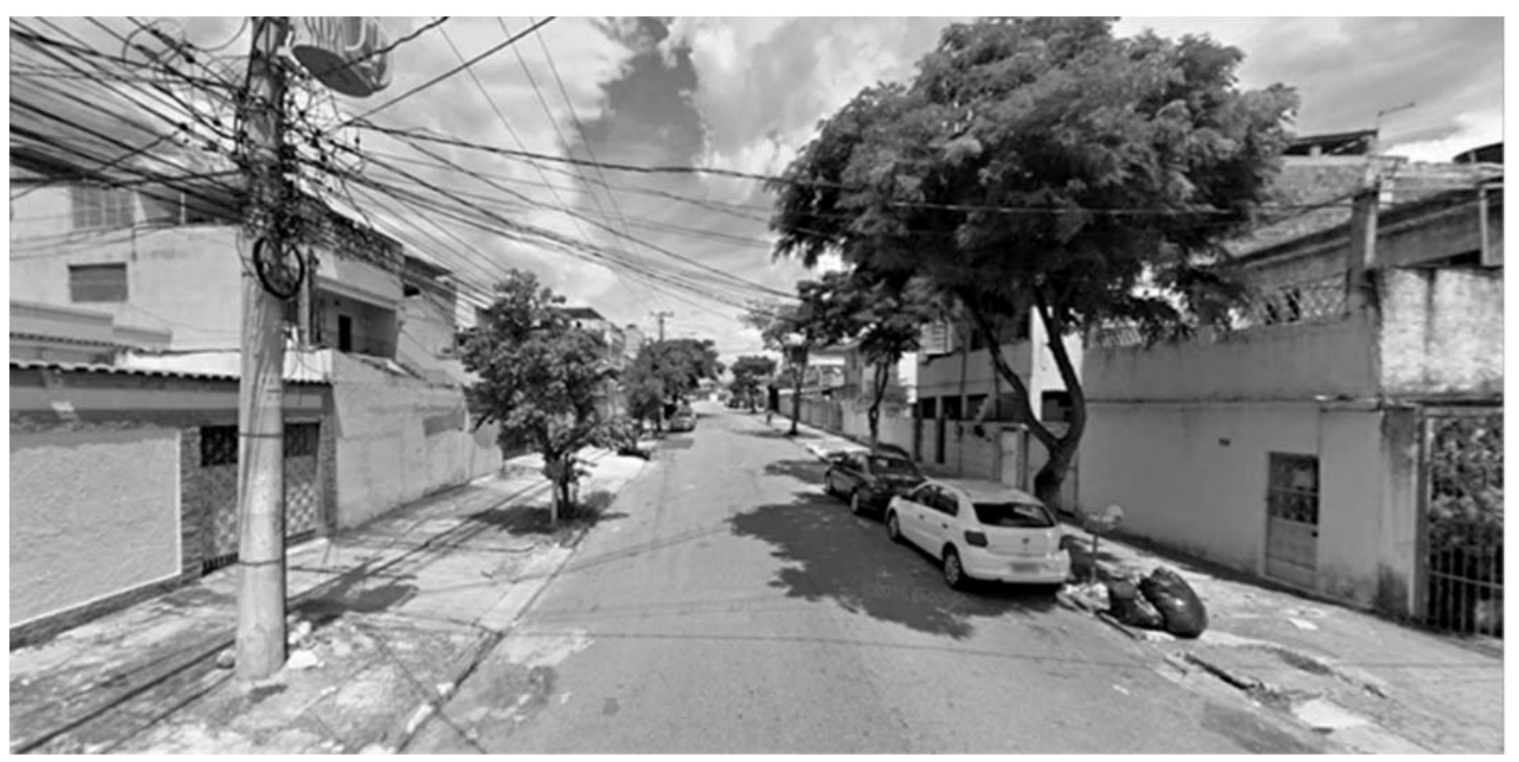

Figure 3. Street in the residential neighbourhood of Irajá, as an illustration of 'scenario I'. Source: Google Street View.

The first scenario is comprised of numerous, private coexisting realms (Figure 3), each of them located in individual lots, disconnected from each other: walled houses, featuring a very clear physical demarcation of the border between public and private environments. The condition of the street demonstrates a lack of public maintenance, functioning merely as a means of circulation and access to the private dwelling spaces. In this first scenario, the walls are the dominant element of the landscape, serving to reinforce the separation of previously established private plots: there is no place for the 'common'. The observation of this scenario where life tends to be restricted to the private realm of the house refers to questions raised by Guy Debord (196I) in his critique of modern society:

The new prefabricated cities clearly exemplify the totalitarian tendency of modern capitalism's organization of life: the isolated inhabitants (generally isolated within the framework of the family cell) see their lives reduced to the pure triviality of the repetitive combined with the obligatory consumption of an equally repetitive spectacle. (...) Someone posed the question, 'What is private life [vie privée] deprived [privée] of?' Quite simply: of life itself, which is cruelly absent. People are as deprived as possible of communication and of self-fulfillment; deprived of the opportunity to personally make their own history. 
In the second scenario, a fundamental component transforms the urban environment, making it essentially different from the previous one. We refer here to the presence of entrepreneurial activities: a window is opened, a sign is placed, or an awning is deployed over the sidewalk or small porch attached to the house to sell a product or service in the residential neighbourhood (Figure 4). They are subtle operations that proliferate within the structures of the residential street and silently subvert the mono-functional nature of the neighbourhood, responding to various economic, cultural and social demands. Such devices, or tactics, in the sphere of both daily life and work modify the "status quo" in these neighbourhoods by promoting the interaction between private and public spaces.

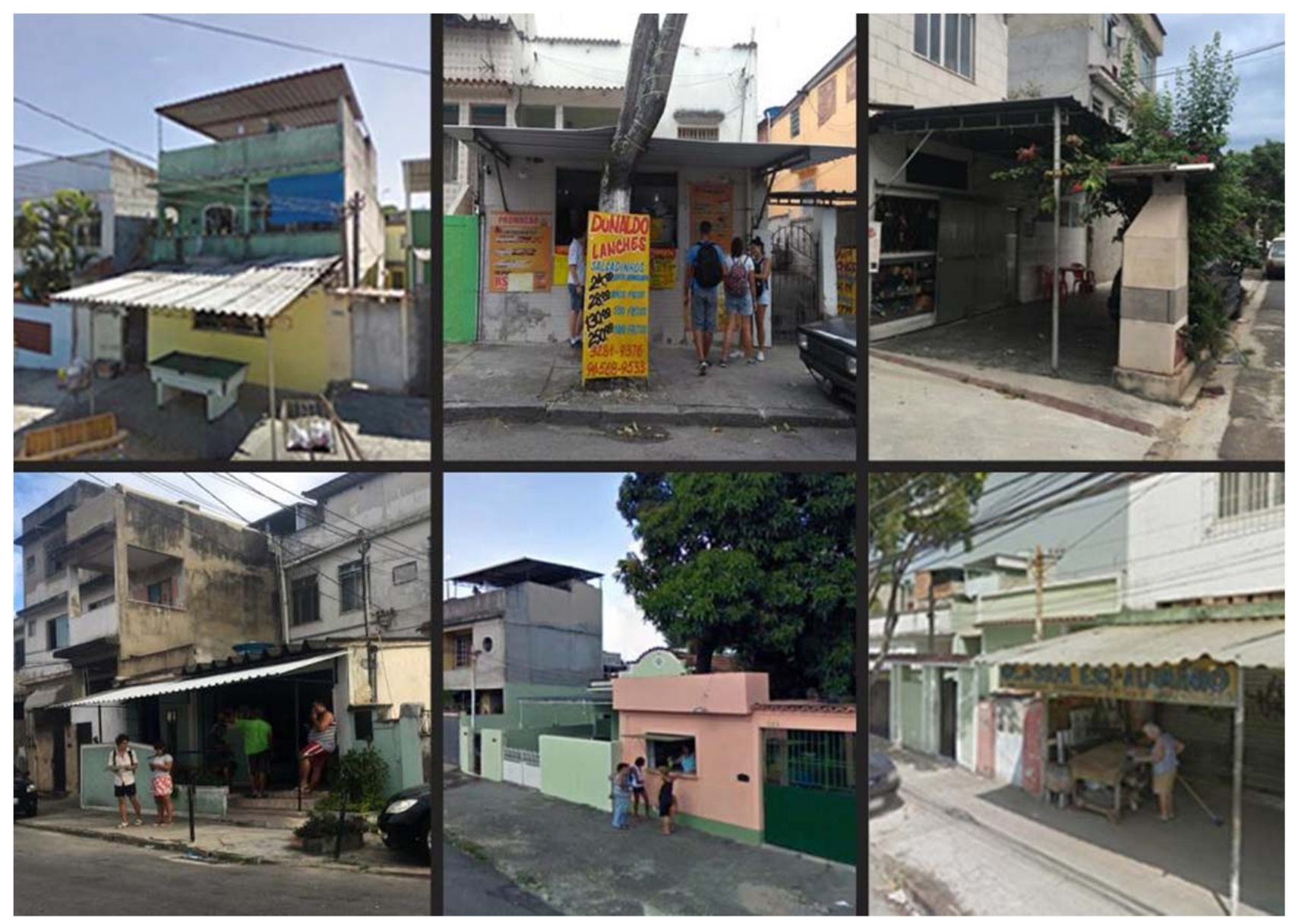

Figure 4. Home-based informal activities in the residential neighbourhood of Irajá, as illustration of 'scenario 2'. Source: authors' selection from Google Street View. 


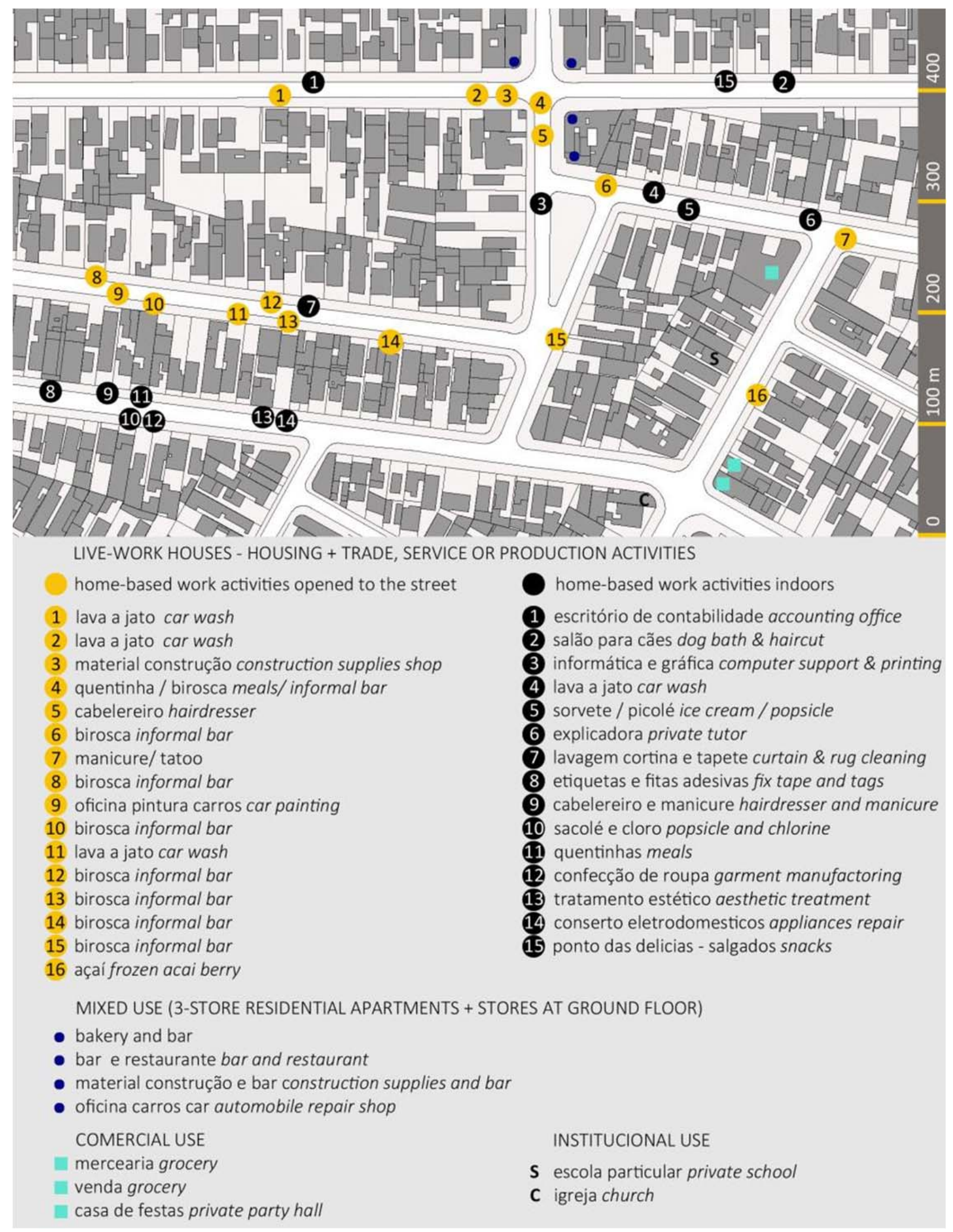

Figure 5. Mapping of home-based informal activities in a fragment of the residential neighbourhood of Irajá, Rio de Janeiro. Source: authors' elaboration based on a Google search. 
These practices are related to the "house" in terms of physical property: they transform the building to accommodate workspace. However, they also result in transformations within the family ways of living and the surrounding community as they are interwoven with local lifestyles and reimagine social interactions beyond the walled family structure as spilling out on to the street and wider neighbourhood. Through inviting neighbours to ring the bell and interact with the domestic family life, they promote even more transformative interactions. Overhanging coverings, or small add-on sheds, proliferate across local streets forming spaces of greater integration between public and private domains. This breaking down of both the formal and informal barriers segregating domestic and public spaces blurs these borders and creates a transitional space that has the quality of the "in-between" (Hertzberger, 1996), encouraging users to stay on the sidewalk and to use it as a common space (Figures 5,6 and 7).
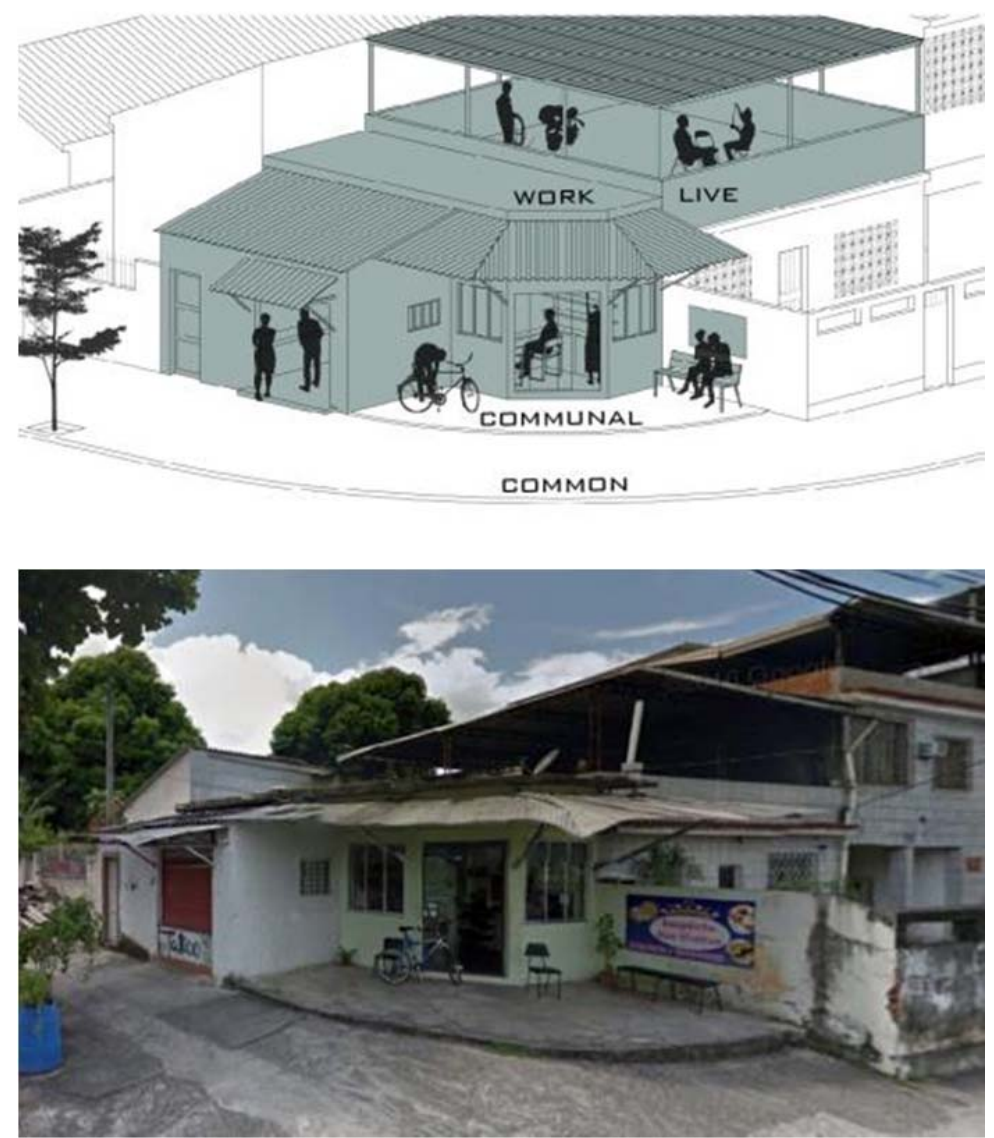

Figure 6. Scheme of a home-based 'Manicure and Tattoo' salon in Irajá, Rio de Janeiro. Source: authors (collaboration: Daniel Moraes)

The overhanging coverings are deployed in front of the houses, on the frontal setback or even outside the private plot, on the public sidewalk. They are also built on top of the houses, transforming the existing flat roof slab into a living space. They are often used as a shelter for productive or commercial activities, but they are, above all, spaces of sociability. Solving practical and functional issues, overhangs extend the space occupied by the house, enabling small-scale entrepreneurial activities to take place: promoting 
social and cultural practices which encourage community interaction previously repressed in these strictly residential streets. No longer is the border between street and private realm reinforced by physical and visual barriers (Figures 6,7 and 8). In areas where streets are populated by such entrepreneurial activities, urban life is activated, offering more favourable conditions for certain daily social practices. During our on-site visits and our observations of street life, we noticed numerous signs that pointed to the various social practices taking place, such as: greetings, informal conversation and coexistence between neighbours. These diverse practices all served to provide a greater appropriation of sidewalks. As an example, some of the residents reported that the street where the "patty factory" is located - which offers a communal porch facing the street where neighbours usually sit and chat - is safer than another street on the other side of the same block which is for strictly residential use and suffers from a higher robbery rate. In the close vicinity of the overhanging porch, an even older habit typical of the suburbs of Rio de Janeiro can be observed: the tradition of placing chairs on the sidewalk in front of residential houses. This tradition is at risk of being lost in the streets with predominantly residential and walled houses.

Fashioned from tubular iron structures, plastic tubes and lightweight roofing tiles, plastic canvas or plastic tarpaulins, the overhanging coverings shelter displays of products for sale and professionals repairing appliances or manufacturing artefacts such as metal frames; all while they take part in the life of the street and greet their neighbours. Meanwhile, residents sitting in chairs, chat on communal porches, alongside spaces dedicated to productive activity. (Figures 4,6,7 and 8).

Another important commercial activity that thrives - and according to residents also creates spaces for leisure and a vibrant social life in these neighbourhoods - is the "birosca" (Figure 8): an informal bar where beer and pastries are sold and a barbecue is prepared on weekends, inviting clients to sit at tables along the sidewalk.

On this particular street corner, the plot has been subdivided and many houses have been built within its confines (Figure 9). There are three small shops and each features a distinctive public-private gradation. At the corner, there is a window from which the seller has a wide view of the street and which customers also use to stop by to chat. In another house, the overhanging roof built over the sidewalk defines a workspace protected from both sun and rain, fully open and integrated into the public space that is the street. The roof already housed a bicycle repair shop and is now also used as a car wash that animates public life in that urban space. The third commercial space is a beauty salon. Although organised indoors and not visible from the street, its entrance door is connected to the sidewalk by a small public hall. This corner is a lively place in the neighbourhood.

These practices are all evidence of the knowledge the users possess. These anonymous "arts of practice" that invent ingenious creations offer hope that from within the interstices of the imposed codes, life can be injected in to lacklustre spaces that are the direct result of an imposed technocratic system: bestowing on them new and local meanings. Through small subversions with unpretentious purpose and undetermined political goals, they improve the otherwise alienating nature of everyday life with "wonders". 
Live-work Tactics in the Suburban House and their Effects on Public Spaces
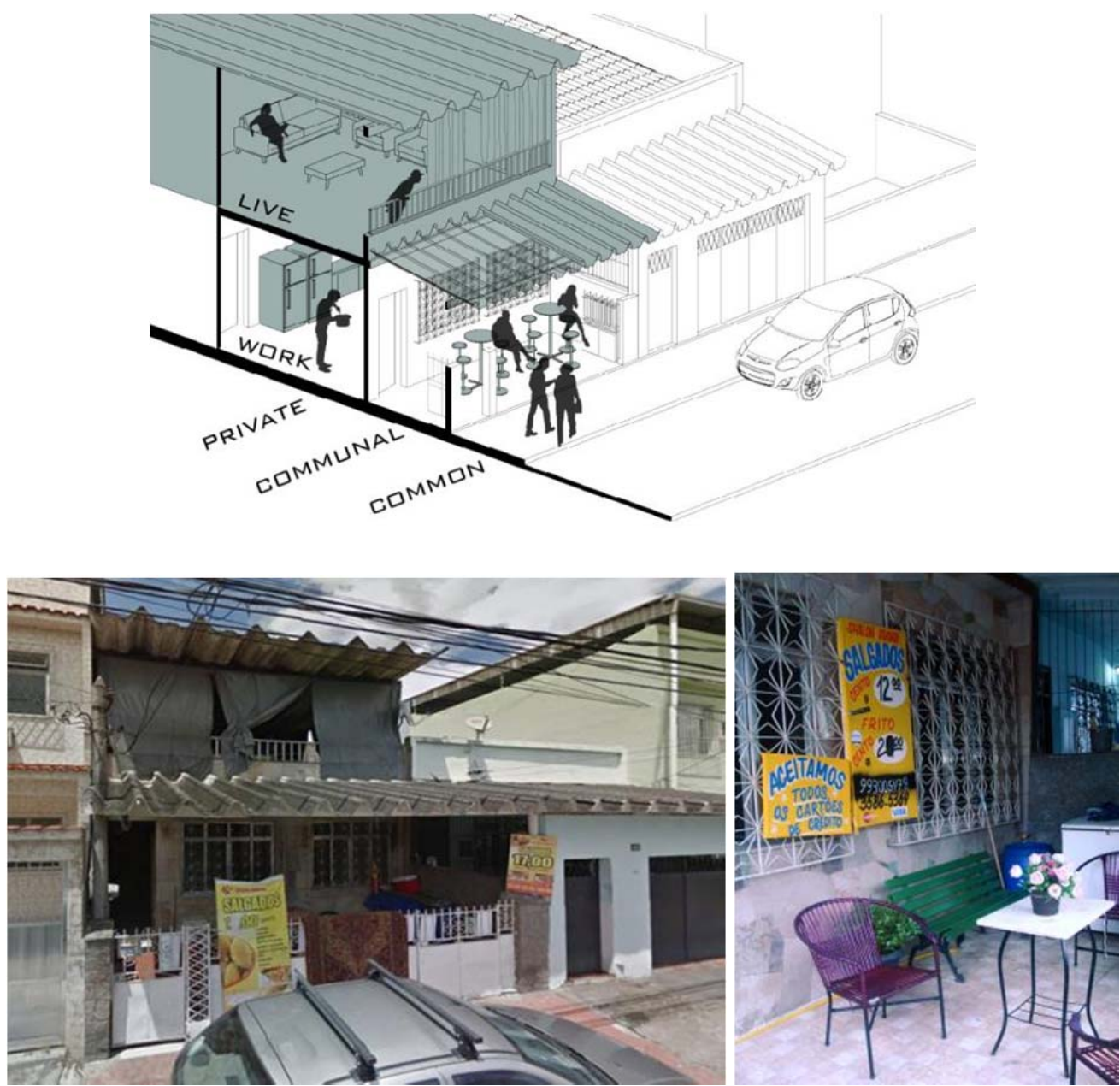

Figure 7. Scheme of a home-based patties factory in Irajá, Rio de Janeiro. Source: author (collaboration: Daniel Moraes)
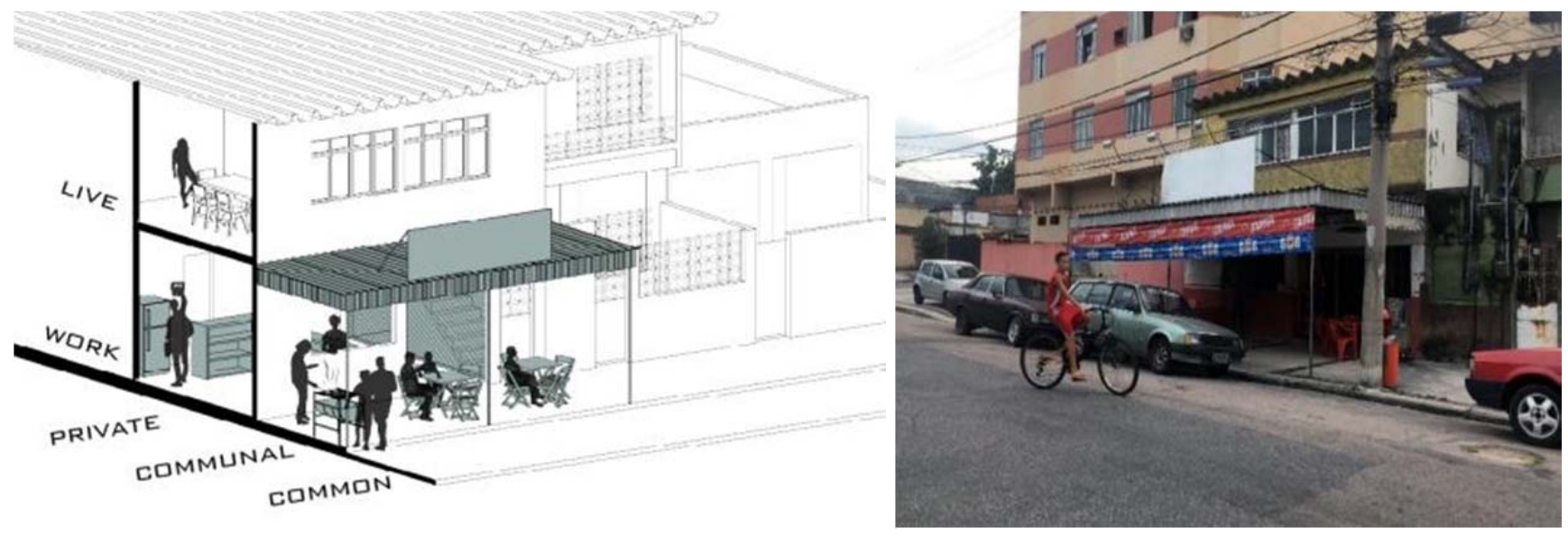

Figure 8. Scheme of a home-based birosca in Irajá, Rio de Janeiro. Source: authors (collaboration: Daniel Moraes) 

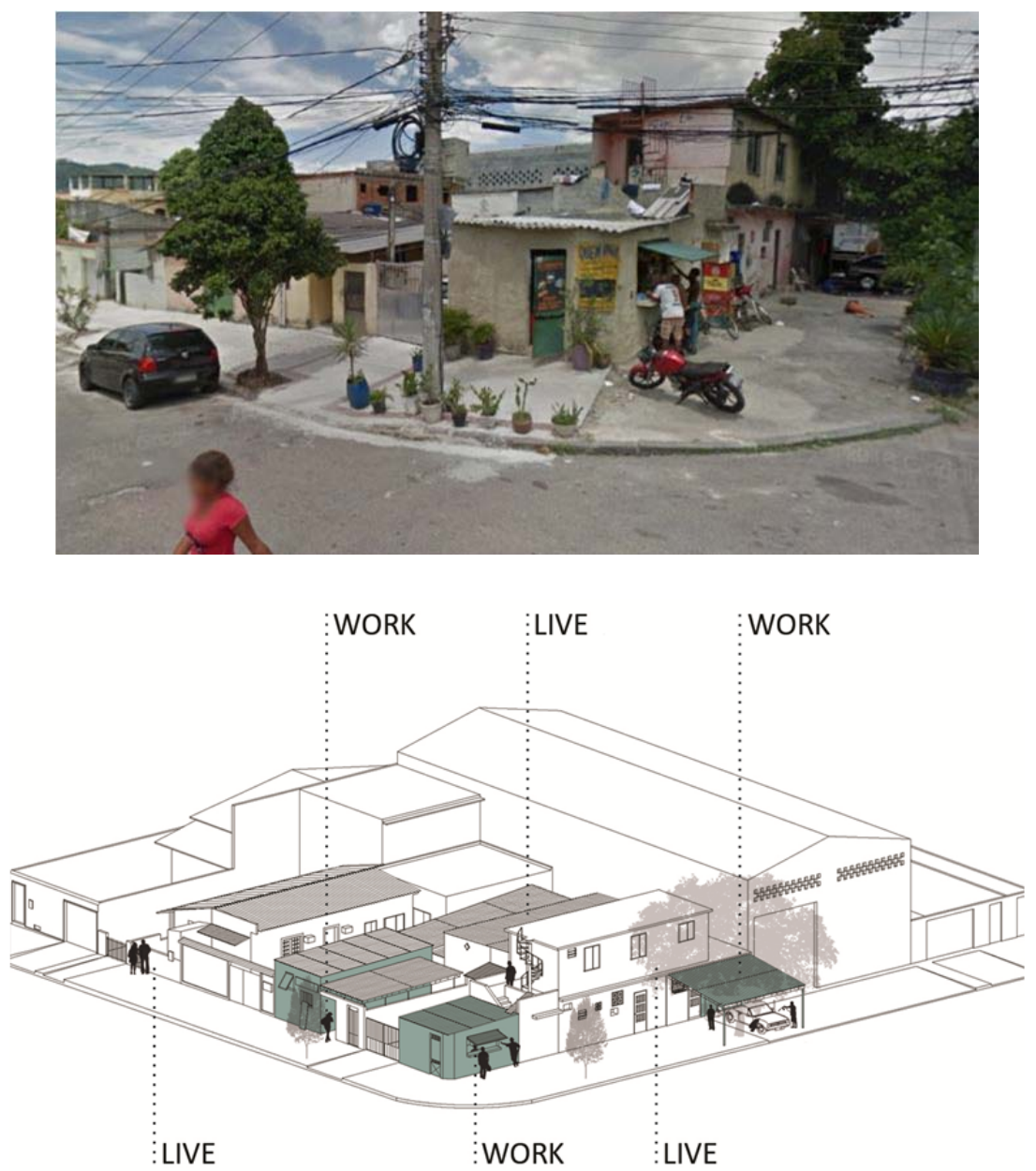

Figure 9.Three home-based business premises on a street corner of Irajá, Rio de Janeiro. Source: authors (collaboration:Vinicius Medeiros) and photo: from Google Street View.

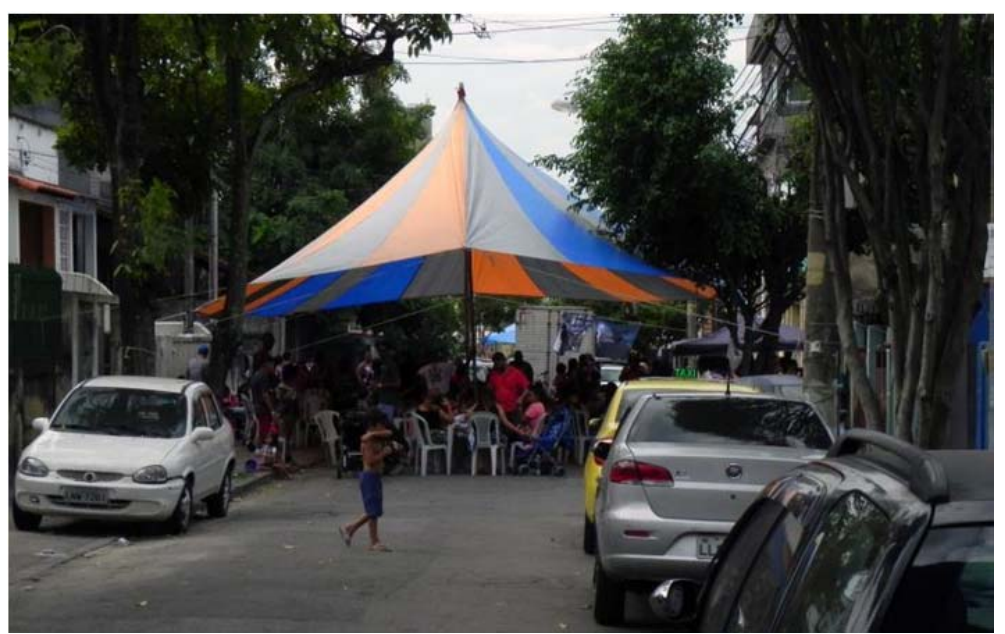

Figure 10. Saint-Georges Day in a residential street of Irajá, Rio de Janeiro. Source: Pedro Augusto Teixeira, 2018. 


\section{Results}

Despite the analysed urban fabric's precarious process of formation, the characteristics of its built environment - narrow lots, densely built, one to three floors, buildings aligned to property limits or with small front yard space (which results in a continuous urban facade) - don't restrict home-based entrepreneurial activities or therefore, the development of fine-grained, mixed-use neighbourhoods in the peripheries of Rio. In the suburbs of Rio de Janeiro, the front yard is a flexible space which offers residents the opportunity for curation and by extension to establish the kind of relationship between the house and the street that they see fit. These spaces can work as buffer zones between the house and the sidewalk, or as an expansion to the house; sometimes serving as an intimate living space for family and friends, protected from the street by raised walls or, on the contrary, as an interface device for increased exchange with the street.

Although the existence of a physical barrier marking the boundary of the private property is a constant feature, the varying degrees of visibility and demarcation of what is public and private go beyond the usual rigidity of this boundary. Low walls and fences allow for visual contact between front yards and porches, and between balconies and front facing windows and the surrounding urban context. In other houses, higher walls protect the private space in the front portion of the house. The protection of the private and intimate spaces of the house is identified as a cultural value in these suburban neighbourhoods: the high walls do not only serve to provide security but also to provide privacy.

However, the logic of demarcating private property is suspended by: opening gates to the street; sitting in the doorway or placing chairs on the sidewalk; or by creating transitional spaces that tend to blur the border, spaces which are normally associated with commercial activities. These spaces - whether inside the private plot or on the sidewalk - are designed to be inviting to neighbours and passers-by, thus giving support to social activities.

The traditional definitions for the concepts of "public" and "private" that apply to the standard plot allocation system are reconfigured by the physical and spatial transformations of the suburban houses driven by their residents. The initial setup is clear and without nuances: private plots, public streets and sidewalks. But in practice, the gradation is diverse and is born from the combination of a set of elements including the house and its yard, porch, shed, walls, fence, gates, windows, balconies and overhanging roofs. The complex combination of these elements inside the private plot - and sometimes extending on to sidewalks - gives birth to a diversity of intermediate spaces featuring both specific nuances related to public-private gradations and forms that encourage physical and visual interactions between the private plot and the public space. The article presents findings showing that a house, in Rio de Janeiro suburbs, includes both public and private spaces. 


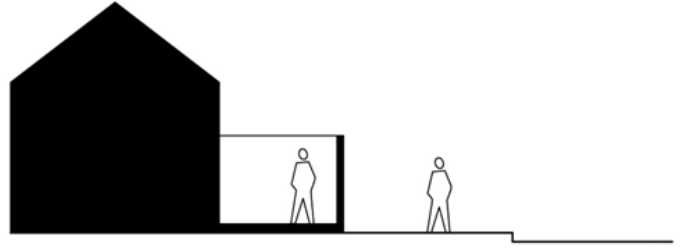

PRIVATE $\quad[$ IN PUBLIC OPPOSITION

TO]

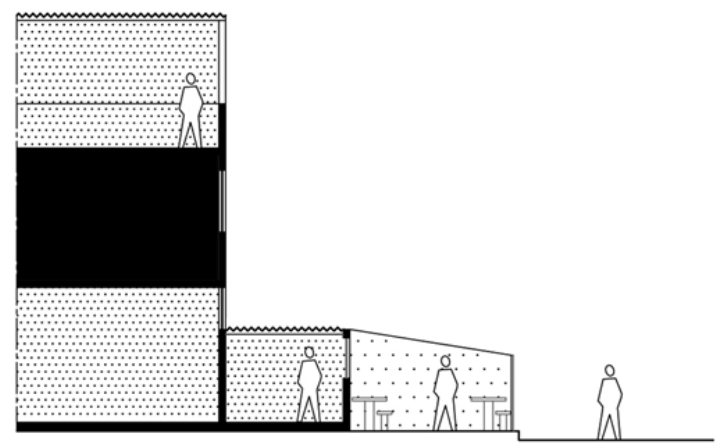

PRIVATE - PUBLIC GRADATION

Figure II. Rio suburban houses public-private section-diagram.

Source: authors, 2019.

\section{Conclusion}

Despite a functional zoning legislation that does not allow for commercial and residential uses to coexist in the same plot, the socio-economic context combined with inoperative monitoring by the city administration has stimulated informal home-based productive activities. The result is the transformation of some areas into hybrid environments, which helps to mitigate the fragmentary and homogenising character of functional zoning codes and this affects urban space.

Home-based, informal productive activities in the suburbs of Rio de Janeiro boost local economy and transform the daily routines of local residents and their built environment. In response to users' needs, which were not considered on planning, these activities create devices that are more conducive to enhancing their users' social lives, whilst in public space. Triggered by the need to generate income, they also help to improve the common by: creating small shops and facilities within walking distance; shifting interactions between houses and street life, creating spaces in which to encounter fellow residents and engage in collective interaction; and intensifying the use of the sidewalks, activating urban life and transforming the street into a more inhabited, cared for and safe space. Their actions generate public space. Spontaneous cultural and social practices demonstrate that residents are looking for alternative conditions to those typical of bucolic spaces created by functional zoning in these residential suburban areas. Communities are being transformed through occupant adaptations which lead to busier streets which, in turn, promote social interaction and entrepreneurial activities that encourage cooperation/collaboration among inhabitants.

The transformations, or 'arts of practicing', playing out in the suburban neighbourhoods of Rio de Janeiro are valuable clues as to identifying possible improved city planning and housing policies from a wider angle too. They demonstrate alternatives to hegemonic mono-functional housing developments - to single-family townhomes closed within gated communities - an urban and housing model that continues to be used repeatedly in Brazil, all the while further contributing to the formation of increasingly segregated cities. The home-based work lifestyle that develops spontaneously in the suburbs of Rio 
de Janeiro is in line with idealised strategies being advanced in developed countries across the world, by American author Thomas Dolan and British author Frances Holliss for example. The proposal of a multifunctional live-work unit is approached as a citywide strategy due to its potential for impact on both the optimisation of resources and reduction in the demand for transportation, in addition to the qualification of urban space in suburban neighbourhoods. The concept of "Zero Commute Housing" indicated in the title of Dolan's book (20I2) refers to architectural typologies that are able to reduce the need for individual or collective transportation, whether for work or for other daily activities. The potential for use, related to productive activities, is also valued by Dolan - in terms of neighbourhood vitality - over the alternative of strictly residential neighbourhoods.

Holliss (2015), in turn, calls for a review of how buildings and cities are thought of, particularly in the face of informational capitalism and the unprecedented number of women in the labor market. She argues for the pressing issue of how transformations in the lives of individuals should be strongly linked to the transformations in the ways in which buildings and whole neighbourhoods are conceived. She also champions the social, economic and environmental benefits that the encouragement of the "workhome" model could provide (Holliss, 2015, pp. I68-197).

However, Holliss also points out that in England, as is the case in many countries, both building and urban regulations are still based on a mono-functional paradigm: this continues to be a major drawback.

Regulations rooted in the industrial past discourage this working practice and as a consequence severely restrict the possibility of developing buildings and city districts appropriate to contemporary home-based employment practices, in part, generated by informational capitalism. Changes to planning frameworks, property taxation systems and tenancy agreements in social housing are urgently needed. They would help bring this practice and these buildings out from the shadows Holliss, 2015: 165

The 'live-work' tactics analysed as proliferating in the suburbs of Rio are finally recognised as valuable lessons as the demonstration that these small-scale changes, born out of ingenuity and intrinsic to local ways of entrepreneurial life, have the potential to alter the urban environment and the notion of public space. As we have demonstrated, changes to the home alter the dynamic of urban life, which can radically transform the neighbourhood, its public spaces network and as such the surrounding community. The lessons learned from these seemingly-ordinary actions, arising from the common man, are illustrative of possible alternative route to reimagining the city.

\section{Acknowledgement}

This research is supported by a series of study grants given to the first author by the Brazilian Council for the Improvement of Higher Education (CAPES) and the Canadian Emerging Leaders in the Americas Program (ELAP), for the development of her PhD dissertation. 


\section{References}

Abreu, M. A. (1987). A Evolução Urbana do Rio de Janeiro. Rio de Janeiro: IPLANRIO/ Zahar. Angélil, M. and Hehl, R. (eds.)(20I3). Cidade de Deus! City of God! Working with Informalized Mass Housing in Brazil. Berlin: Ruby Press.

Bonduki, N.; Rolnik, R. ( 1979). 'Periferia de São Paulo: reprodução do espaço como expediente de reprodução da força de trabalho', in Maricato, E. (ed.) A produção capitalista da casa e da cidade no Brasil industrial. São Paulo:Alfa-Omega, pp.I I7-I54.

Certeau, M. de (1984). The practice of everyday Life. Berkeley: University of California Press.

Costa, M. L. P. M.; Silva, M. L. P. (eds.) (20I7). Carlos Nelson Ferreira dos Santos. Sementes Urbanas I. Niterói: Eduff.

Coupland, A. ( 1997). 'A History of Mixed Uses', in Coupland, A. (ed.) Reclaiming the city: mixed use development. London: E \& FN Spon, pp. 3I-62.

Dolan, T. (20I2). LIVE-WORK Planning and Design: Zero-Commute Housing. Hooken, ES:Wiley.

Debord, G. (196I).'Perspectives for Conscious Changes in Everyday Life' in Internationale Situationniste \#6, Paris.

Fernandes, N. da N. (20I I). O Rapto Ideológico da categoria subúrbio: Rio de Janeiro I858-1945. Rio de Janeiro: Editora Apicuri/Faperj.

Hetzberger, H. (1996). Lições de Arquitetura. São Paulo: Martins Fontes.

Holliss, F. (20I5). Beyond Live/Work:The Architecture of Home-based Work. London, New York: Routledge.

IBGE- Instituto Brasileiro de Geografia e Estatística (2010). Dados básicos: IBGE-microdados dos Censos Demográficos 199I e 2000. Available at: https://biblioteca.ibge.gov.br/index.php/biblioteca-catalogo?view=detalhes\&id=298009 (Accessed: 18 May 2017). 
Live-work Tactics in the Suburban House and their Effects on Public Spaces

IBGE- Instituto Brasileiro de Geografia e Estatística (2017). Diretoria de Pesquisas, Coordenação de Trabalho e Rendimento. Pesquisa Nacional por Amostra de Domicílios Contínua, March 2017. Available at: http://www.ibge.gov.br/home/estatistica/indicadores/trabalhoerendimento/pnad_continua/ (Accessed: 18 May 2017).

Jacobs, J. (2000) [196I]. Morte e vida nas grandes cidades. São Paulo: Martins Fontes.

Lassance, G., Varella, P., Capillé, C. (20I2). Rio Metropolitano: Guia para uma arquitetura. Rio de Janeiro: Rio Book's.

Lefebvre, H. (1991) [1968]. O Direito à Cidade, São Paulo: Editora Morais.

Pechman, R. (1985). Gênese do mercado urbano de terras, a produção de moradias e a formação dos subúrbios no Rio de Janeiro. Dissertation. Universidade Federal do Rio de Janeiro.

Reis Filho, N. G. (1978). Quadro da Arquitetura no Brasil. São Paulo: Perspectiva.

Santos, C. N. F. dos; Vogel, A.; Mello, M.A. S.; Mollica, O. et al (1985). Quando a rua vira casa: a apropriação de espaços de uso coletivo em um centro de bairro. 3. ed. São. Paulo: Projeto FINEP; IBAM.

Santos, J.J. M. (1996). De freguesias rurais a subúrbio: Inhaúma e Irajá no município do Rio de Janeiro. Thesis. Universidade de São Paulo.

SEBRAE- Serviço Brasileiro de Apoio às Micro e Pequenas Empresas (20I5). Painel Regional: Rio de Janeiro e bairros / Observatório Sebrae/ RJ. Rio de Janeiro: SEBRAE/RJ. Available at: http://www.sebrae.com.br/Sebrae/Portal\%20Sebrae/UFs/RJ/Anexos/SebraePainel_CidadeRio dejaneiro.pdf (Accessed: 20 March 2019).

Walker, E. (ed.) (2010). lo ordinario. Barcelona: Editorial Gustavo Gilli. 